\title{
Millennials as a Target Segment of Socially Responsible Communication within the Business Strategy
}

\author{
Margareta Nadanyiova ${ }^{1}$, Subhankar Das ${ }^{2}$ \\ ${ }^{1}$ University of Zilina, Slovakia \\ 2Duy Tan University, Vietnam
}

\begin{abstract}
The topic of corporate social responsibility is currently very up-to-date and is gradually becoming the focus of stakeholder's attention, mainly consumers. Especially, one generation of consumers, Millennials, is considered to be the driving force behind the demand for socially responsible brands and products. The key factor to achieve the positive attitudes of Millennials towards the socially responsible brand is the appropriate communication targeted particularly on this segment. The article is aimed on Millennials as a target segment of socially responsible communication within the business strategy and the determination of the most efficient tools of socially responsible communication with Millennials. This includes the literature review on the issue and analysis focused on the perception of socially responsible communication by Millennials. The secondary data for the analysis were obtained from scientific researches, statistical tables and published professional publications. In order to determine the most efficient tools of socially responsible communication, a questionnaire survey was conducted among Millennials. Based on this, measures for the efficient implementation of socially responsible communication with Millennials are proposed, and its benefits are highlighted, such as strengthening the company's image, improving its reputation, building customer relationships and gaining the customers loyalty to the socially responsible brand.
\end{abstract}

Keywords: Corporate Social Responsibility (CSR), socially responsible communication, marketing communication, consumers' generations, Millennials, sustainability, business strategy 


\section{Introduction}

Currently, the concept of corporate social responsibility is becoming a mantra for companies around the world (Sroka and Szanto, 2018). Its essence lies in the fact that companies focus not only on profit but above all on sustainable growth and development. In addition to their economic activities, they also pay attention to the social and environmental aspects and emphasize that these interests do not have to be contradictory, but conversely, they can work together and thus increase their efficiency (Moravcikova et al., 2017). Around the world, the number of companies that apply CSR principles in their business strategy is growing rapidly (Krizanova and Gajanova, 2016).

One of the motivations for socially responsible business is to improve reputation as well as brand awareness (Kliestikova, Kovacova and Radisic, 2018). The company may achieve this goal only by informing about its activities (Gajanova and Podhorska, 2019). When it invests time and money in CSR, it is indisputable that it should also invest in communication about these activities. Socially responsible communication raises general awareness of CSR, encourages other companies to reconsider their strategies and finally represents a way to raise the level of the entire business environment. However, this requires a sophisticated strategy of socially responsible communication to all stakeholders. The company should first segment its stakeholders and "customize" the communication to these target segments, i.e. adapt the message content and communication channel.

One of the consumers' generations, so-called Millennials, is currently considered to be the driving force behind the demand for socially responsible brands and products. It is a generation that has already reached adulthood, and therefore it is economically active and increasingly important in the market of workforce as well as consumers (Bucic et al., 2012; Fry, 2016). Many authors and studies claim that this is a generation educated in the field of CSR and thanks to their representation in the traditional market as well as the labour market with the power to require companies to be socially responsible (Nielsen, 2018). The main reason for focusing this generation is mainly its growing importance and the power of its impact on companies.

For the reasons mentioned above, the article is aimed on Millennials as a target segment of socially responsible communication within the business strategy and the determination of the most efficient tools of socially responsible communication with Millennials. It includes a literature review on the issue of socially responsible communication from the perspective of foreign as well as domestic authors and analysis focused on the perception of corporate social responsibility and its communication by Millennials. Based on the analysis and questionnaire survey results, measures for the efficient implementation of socially responsible communication with Millennials are proposed, and its benefits are highlighted.

The issue of the socially responsible communication has been researched and analysed by many foreign and domestic authors, and remains actual. 
The main goal of socially responsible communication is to make the CSR activities of the company visible through a variety of communication tools. According to Morsing and Schultz (2006), through socially responsible communication, companies want to report that they are ethically and socially responsible. In order to achieve the desired results, they have to involve stakeholders in this process. In particular, they draw attention to the importance of engaging stakeholders in long-term value creation, and in order to achieve this goal, a company have to develop CSR communication from a monologue to dialogue and dialogue-based relationships.

Scholder et al. (2006) claim that CSR communication is essential to create and maintain the desired reputation effects.

McWilliams and Siegel (2011) consider socially responsible communication as an important part of successfully achieving the CSR's strategic objectives and an essential part of particular CSR activities.

Luo and Bhattacharya (2009) emphasize the right timing of socially responsible communication as well as the fact that it needs to be designed and perceived as a coherent concept, since companies investing to CSR can create intangible assets in the form of brand loyalty, customer loyalty, reputation, improving sales performance and stakeholder identification.

According to Wagner et al. (2009), the communication strategy for the CSR plays a key role and influences stakeholders' attitudes towards the business.

Goluchowski et al. (2015) state that the use of gamification and gaming features (mechanisms) in the socially responsible communication is a good way to improve the communication process. They focused on how gamification can be used to improve social media-based CSR communication of companies with their stakeholders.

It is obvious, that the CSR concept requires more than any other business strategy. It needs a credible and consistent communications policy. Companies can plan socially responsible communication as a strategic communication concept and implement it as a more content-based approach, by targeting specific groups or using special CSR teams (Bruhn and Zimmermann, 2017).

Over the years, several authors have dealt with the issue Millennials as a target segment of CSR including socially responsible communication.

Millennials, born in 1981-1996, are considered the first global and technologically capable generation in the world and is also known as Generation Y, Generation Next, Digital Generation, Nexters, Echo Boomers, Google Generation, Why Generation, etc. These terms are commonly used as synonyms and are derived from the logical context and continuity of segmentation stratification according to the Pew Research Center (McCrindle, 2014; Fry, 2016).

Fry (2016) state that Millennials are currently the most numerous adult generations thanks to which they are considered the most consumer-oriented generation with the greatest impact on the world economy. At the same time, according to a Euro RSCG 
Worldwide survey of 3,000 respondents from around the world, they are so socially responsible that they see themselves as the generation which can change the world (Bucic, Harris and Arli, 2012). It is thus a generation that does not like the way previous generations have treated the planet and that sees an urgent need to reduce its carbon footprint by changing its approach to consumption and thus contribute to a healthier life (Arnold, 2018). Aware of their strength, they demand that companies behave socially responsibly and become active creators of long-term social sustainability on a global scale. They focus not only on the most current issues, but also seek solutions to optimize the possible future impacts of their activities (Landrum, 2017). This means that they put pressure on companies so that their production meets not only the basic conditions regulated by legislation, but also to accept higher social commitments in the form of switching to products that are ecological, natural or do not burden the environment in any way (Nielsen, 2018). Up to 83\% of Millennials believe that even small changes that they can make themselves can have a major impact on improving the environment (Glass Packaging Institute, 2011). And it is the transition to environmentally responsible and sustainable production that can be one of such changes.

Such an approach to social responsibility significantly distinguishes Millennials from other consumers' generations. It is characteristic not only for consumption, but also for the personnel dimension of the interaction between the company and whole society. Millennials also prefer socially responsible companies as promising employers.

Escareno et al. (2018) examine the knowledge level of Millennials about CSR in determined companies, as well as the way they are influenced by social marketing in their purchase intent.

Lee and Haley (2019) find out, that younger consumers, including Millennials, are more likely to form favourable attitudes toward socially responsible communication (mainly socially responsible ads) and products compared to older consumers.

\section{Methods and Data}

The article is aimed on Millennials as a target segment of socially responsible communication within the business strategy and the determination of the most efficient tools of socially responsible communication with Millennials. This includes providing a literature review on the issue of socially responsible communication from the perspective of foreign and domestic authors as well as analysis focused on the perception of corporate social responsibility and its communication by Millennials. Based on analysis and questionnaire survey results, measures for the efficient implementation of socially responsible communication with Millennials are proposed, and its benefits are highlighted, such as strengthening the company's image, improving its reputation, building customer relationships and gaining the customers loyalty to the socially responsible brand. 
The secondary data for the analysis were obtained from scientific researches, statistical tables and published professional publications. In order to determine the most efficient tools of socially responsible communication, a questionnaire survey was conducted among Millennials.

The aim of the questionnaire survey was to analyse the perception of corporate social responsibility and its communication by Millennials. The sample size was determined using the Sample Size Calculator that forms part of Creative Research Systems' survey software and which is provided as a public service. The calculator determines how many respondents need to be interviewed in order to get results that reflect the target population as precisely as possible. This is necessary to avoid any distortion in the survey information. The process requires a base file to work from, which in this case consisted of population data for the Slovak Republic, and in particular data on those born in 1981-1996. The confidence interval was set at 5\%, with a confidence level of $95 \%$. This means that for the questionnaire survey a 5\% margin of error is assumed. The sample size calculated by the calculator was determined to be 384 respondents. In total, 515 respondents participated in the questionnaire survey.

The questionnaire survey was conducted during the second half of 2019 . The selection of the respondents in the sample set took place at random and was based on the number of Slovak inhabitants born in 1981-1996 that belong to Millennials. The quantitative assessment method was applied to the processing of the information obtained from the questionnaire survey. The data were processed empirically in the form of percentages, with additional written comments and comparisons.

General scientific methods were applied for the processing of the data, such as data collection, excerption, description, comparative analysis, deduction, induction, analysis and synthesis, as well as mathematical methods to evaluate the data collated from the results of the questionnaire survey and to statistical hypothesis testing.

In order to achieve the aim of the article, research hypotheses were set:

Hypothesis 1: More than 50\% Millennials know the concept of CSR.

Hypothesis 2: More than 50\% Millennials consider the use of CSR in the company to be a factor of improving company's reputation.

Hypothesis 3: More than 50\% Millennials consider information on CSR activities in Slovak companies to be sufficient.

Hypothesis 4: More than 50\% Millennials obtain information about CSR in Slovak companies through company websites.

Hypothesis 5: In future, more than 50\% Millennials would like to obtain information about CSR in Slovak companies through social media.

Statistical hypothesis testing is one of the most important statistical inference procedures. The role of statistical inference is to decide on the basis of information from the available choice whether we accept or reject certain hypotheses regarding the basic set. In verifying 
the correctness or incorrectness, we proceeded in accordance with the methodology of statistical hypothesis testing, which consists of the following steps (Rimarcik, 2007):

1. Formulation of the null hypothesis ( $\mathrm{H} 0)$.

2. Formulation of the alternative hypothesis (H1).

3. Determining the level of significance $(\alpha)$.

4. Calculation of test statistics and probability.

5. Decision.

Significance level $\alpha$ was determined at 0.05 . To calculate the test statistic, we used the method testing a single proportion.

\section{Results}

\section{Results of secondary research focused on the perception of corporate social responsibility by Millennials}

Most of the previously realized researches point out the active involvement of Millennials in the process of achieving sustainable development of the whole society (Wheeler, 2018). A survey by Cone Communications shows a significant interest of this generation in participating in socially responsible activities:

- $87 \%$ respondents are willing to buy a product that brings benefits to society or the environment.

- $74 \%$ respondents are willing to volunteer at events with a philanthropic dimension.

- $91 \%$ respondents are willing to substitute a previously preferred brand for another if its higher contribution to building sustainable development of society is demonstrated (Cone Communications, 2015).

Similar conclusions are formulated on the survey results carried out by the Nielsen Agency, where even up to $90 \%$ of respondents preferred ecological products in terms of a real purchasing decision. At the same time, based on the survey, it has been estimated that by 2021, up to a quarter of all products on the market will be sustainable and organic (Nielsen, 2018).

Other researches also show that, in addition to changes in consumption preferences, there are changes in the generation of Millennials in favour of the overall greening of their lifestyles. Such an attitude is typical in the case of almost $75 \%$ of Millennials members.

However, the paradox is that in specific activities, such as waste sorting or energy saving, other generations are in fact more involved than millennials (Glass Packaging Institute, 2011). From the survey of Shelton Group, it is also clear, that Millennials are much less involved in day-to-day sustainable behaviour activities compared to other generations. The results of this survey show that Millennials delegate socially responsible behaviour to companies in whose activities they participate, either in the form of volunteering or by deciding to buy their products (Shelton Group, 2017). 
These findings thus contradict the conclusions of the Euro RSCG study (2011), according to which Millennials believe they are the generation that can change the world, even at the level of individual efforts of each one. Hume (2010) also draws attention to the discrepancy between the internal beliefs and external manifestations of Millennial; it means by identifying the declared strong emphasis on environmental protection, recycling, saving resources and eliminating environmental damage on the one hand, but a real lack of own initiative on the other hand.

It follows from the above mentioned, that although Millennials declare their willingness to contribute to socially responsible activities, this is mainly reflected secondarily in their purchasing preferences for socially responsible products than primarily in their environmental behaviour such as waste sorting or energy saving (Buss, 2012). The issue of social responsibility thus overlaps with the ecological dimension of production, while the social and economic pillars represent only marginal areas of interest for Millennials, who often do not even identify these two pillars with corporate socially responsible behaviour (Berthiaume, 2015).

According to a survey by NMS Market Research, companies currently use for promotion their socially responsible projects mostly their websites (85\%). However, most of them think that this has only minimal benefit for the resulting effectiveness of marketing communication. On the contrary, the greatest potential lies in social media. Currently, social media are used in socially responsible communication activities by $56 \%$ of companies, and it is expected this share will rise to two-thirds soon and surpass the dominant position of the website (MEDIAGURU, 2015). An important tool of socially responsible communication of companies continues to be $\mathrm{PR}$, in the form of media relations, which are implemented by up to $70 \%$ of the surveyed companies. Almost $20 \%$ of the surveyed managers see the potential in this communication tool. Graph 1 shows the future trends in the use of marketing communication tools by socially responsible companies and their potential to reach Millennials. 
Graph 1: Future trends in the use of marketing communication tools by socially responsible companies and their potential to reach Millennials.

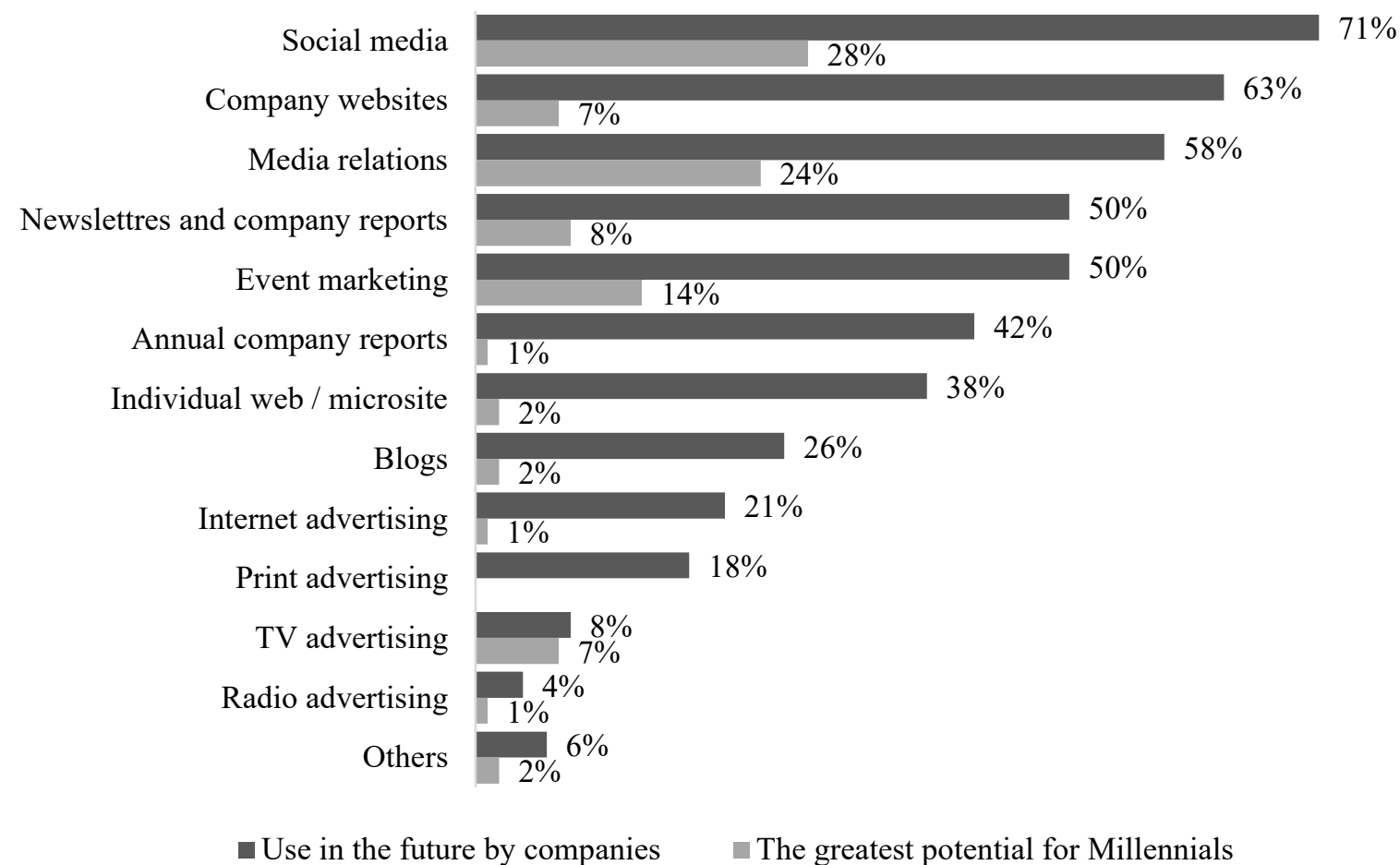

Source: Own processing according to NMS Market Research (MEDIAGURU, 2015).

\section{Results of questionnaire survey focused on the perception of corporate social responsibility and its communication by Millennials}

Of the 515 respondents in the sample set, 321 (62\%) were female and 194 (38\%) male. The results of the questionnaire survey show that $73 \%$ respondents know the CSR concept. $68 \%$ respondents consider the involvement in social responsibility as a necessary part of corporate strategy. According respondents, the most important benefits of implementation CSR in companies is improving company's reputation (89\%), strengthening its image (74\%), building customer relationships (55\%) and gaining the customers loyalty to the socially responsible brand (42\%). As the most important area of CSR, most of respondents (52\%) identity the environmental pillar, next it is the social pillar (36\%) and the least important area is the economic pillar (12\%). As the best-rated activities in environmental responsibility, they indicate eco-friendly behaviour, such as an investment in green technologies, reduce emissions, and support projects to restore nature. The best-rated activities in social responsibility include a strong stance against child labour, employee care, their safety and education as well as corporate philanthropy. As the most important activities in economic responsibility, respondents consider making profit in an honest and ethical manner, compliance with legal standards and payment of taxes, quality products at a reasonable price, and vigorously rejecting corruption. From the results it is clear, that $85 \%$ of respondents are satisfied with the amount of information on CSR activities in Slovak companies. They obtain this information from company websites (62\%), social media (51\%), annual company reports (45\%), CSR 
reports (33\%) and newsletters (25\%). In terms of content, they prefer videos, written report and interactive web sites. In future, they recommend companies to focus their socially responsible communication on social media (86\%), company website (56\%), newsletters (42\%) and media relations (20\%).

\section{Verification of statistical hypotheses}

To verify the statistical hypotheses, we used the method testing a single proportion.

The hypothesis testing for a single proportion includes the following steps:

1. Determination of the null hypothesis:

$$
\mathrm{H} 0: \pi=\pi_{0}
$$

2. Determination of the alternative hypothesis:

$$
\mathrm{H} 1: \pi>\pi 0
$$

3. Selection of the significance level

$$
\alpha=0,05
$$

4. Calculation of the sample proportion:

$$
p=\frac{m}{n}
$$

where $m$ is the number of respondents which indicate the particular option and $n$ is the total number of respondents.

5. Satisfaction of the condition

$$
n * \pi_{0} *\left(1-\pi_{0}\right)>5
$$

Application of the test criteria:

$$
T=\frac{p-\pi_{0}}{\sqrt{\frac{\pi_{0} *\left(1-\pi_{0}\right)}{n}}}
$$

6. Critical field of the test:

Use the tables of the normalized normal distribution to find the critical value for the right-tailed test $z_{2 \alpha}$.

$$
T>z_{2 \alpha}
$$

7. Decision on the test result:

If the inequality does not apply, do not reject the hypothesis $\mathrm{H}_{0}$.

If the inequality applies, reject hypothesis $\mathrm{H}_{0}$, i.e. accept the alternative hypothesis $\mathrm{H}_{1}$. 
Results of verification of statistical hypotheses are shown in Table 1.

Tab. 1: Verification of statistical hypotheses

\begin{tabular}{|c|c|c|c|c|c|}
\hline $\begin{array}{l}\text { Calculation of the } \\
\text { sample proportion: } \\
\qquad p=\frac{m}{n}\end{array}$ & $\begin{array}{l}\text { Satisfaction of the } \\
\quad \text { condition } \\
n * \pi_{0} *\left(1-\pi_{0}\right)>5\end{array}$ & & & & $\begin{array}{l}\text { tance } \\
\text { ection } \\
\text { the } \\
\text { thesis }\end{array}$ \\
\hline \multicolumn{6}{|c|}{$\begin{array}{l}\text { Hypothesis 1: } \\
\qquad \begin{array}{l}\mathrm{H}_{0}: 50 \% \text { Millennials know the concept of CSR. } \\
\mathrm{H}_{1}: \text { More than } 50 \% \text { Millennials know the concept of CSR. }\end{array}\end{array}$} \\
\hline & & & & & \\
\hline \multicolumn{6}{|c|}{$\begin{array}{l}\text { Hypothesis 2: } \\
\text { } \mathrm{H}_{0}: 50 \% \text { Millennials consider the use of CSR in the company to be a factor of improving company's } \\
\text { reputation. } \\
\mathrm{H}_{1} \text { : More than } 50 \% \text { Millennials consider the use of CSR in the company to be a factor of improving } \\
\text { company's reputation. }\end{array}$} \\
\hline & & & & & \\
\hline \multicolumn{6}{|c|}{$\begin{array}{l}\text { Hypothesis 3: } \\
\quad \mathrm{H}_{0}: 50 \% \text { Millennials consider information on CSR activities in Slovak companies to be sufficient. } \\
\mathrm{H}_{1} \text { : More than } 50 \% \text { Millennials consider information on CSR activities in Slovak companies to be } \\
\text { sufficient. }\end{array}$} \\
\hline & & & 1.6449 & $15.8855>1.6449$ & $\mathrm{H}_{0}$ rejected \\
\hline \multicolumn{6}{|c|}{$\begin{array}{l}\text { Hypothesis 4: } \\
\mathrm{H}_{0}: 50 \% \text { millennials obtain information about CSR in Slovak companies through company } \\
\text { websites. } \\
\mathrm{H}_{1} \text { : More than } 50 \% \text { millennials obtain information about CSR in Slovak companies through } \\
\text { company websites. }\end{array}$} \\
\hline & & & 1.6449 & $5.4465>1.6449$ & \\
\hline \multicolumn{6}{|c|}{$\begin{array}{l}\text { Hypothesis 5: } \\
\mathrm{H}_{0}: \text { In future, } 50 \% \text { millennials would like to obtain information about CSR in Slovak companies } \\
\text { through social media. } \\
\mathrm{H}_{1} \text { : In future, more than } 50 \% \text { millennials would like to obtain information about CSR in Slovak } \\
\text { companies through social media. }\end{array}$} \\
\hline & & & 1.6449 & $16.3394>1.6449$ & $\mathrm{H}_{0}$ rejected \\
\hline
\end{tabular}

Source: Authors.

As is obvious from Table 1, in all cases, the inequality applies, so we reject the hypothesis $\mathrm{H} 0$, we accept the alternative hypothesis $\mathrm{H} 1$.

\section{Discussion}

Based on the analysis and survey results, we can claim, that if socially responsible company wants to communicate effectively with Millennials (whether as prospective employees or customers), it needs to have a clearly defined social responsibility and sustainability of production, not only formally but especially realistically. For Millennials, it is important to know whether their purchasing behaviour or their direct role as employees contribute to solve societal problems and help them meet their long-term sustainability commitments. The implementation of the CSR concept into corporate strategy and its subsequent interaction with Millennials may have many benefits and positive feedback. Thus, companies achieve their economic goals by accepting societal commitments that represent the competitive advantage, and consumers actively 
contribute to the sustainable development of society while maintaining their consumer stereotypes and lifestyles.

In order to optimize the effectiveness of their socially responsible communication, companies have to define the range of their stakeholders and their position. The purpose of marketing communication is then to conduct a dialogue with them in order to find out their expectations in relation to the company and its CSR activities, as well as to improve mutual relations (Lizbetinova et al., 2019; Vetrakova et al., 2018). In this process, both participating sides may confront their views and try to understand the values and attitudes of the other side. However, first it is necessary that companies have to effectively communicate their socially responsible activities in one-way to their stakeholders. Only then stakeholders may to know that the company is aware of its socially responsible commitment, and they have space for dialogue. So, the logical consequence of this monologue then becomes a mutually enriching dialogue.

Even with regard to the dual definition of the relationship between Millennials and socially responsible companies in the level of perspective employees and consumers, the basic criterion for the analysis of socially responsible communication is its division into internal and external.

Into basic tools of internal communication with Millennials belongs employee involvement, that is justified by one of their basic characteristics, i.e. delegating responsibility for sustainable social development and subsequent activation only within the created possibilities to other entities, which in this case is a company. Another important tool is regular meeting of all employees due to their significant tendency to adopt the lifestyle of the aspiration group. Collective meetings of all employees in the members of this generation may evoke the desired effect of belonging and acceptance of common values. The indisputable importance for Millennials has trainings and job interviews, especially with regard to the specifics of this generation in relation to education. However, the potential of this tool needs to be supported by the application of progressive educational methods, which have proved their worth in the formal education of members of this generation. Other tools of internal socially responsible communication with Millennials include notice boards, posters, banners, internal press (newsletter, magazines and annual reports), circulars or e-mails, internal videos, brochures, virtual publications on CSR and intranet, which may play a role as a support tools for above mentioned.

For external communication with Millennials, the modern forms of marketing communication represent an extremely effective tool. These are tools that are characterized by the use of state-of-the-art information and communication technologies and which appeal to the creativity of Millennials. Such tools are mainly product placement, guerilla marketing, buzz marketing, mobile marketing, viral marketing or even neuromarketing, enabling to understand and then optimally use relevant consumer decision-making mechanisms in favour of socially responsible products and activities. Based on the survey results, as a separate tool, it is necessary to highlight social media (in 
the conditions of the Slovak Republic, especially Facebook, Instagram and YouTube), blogs and podcasts, where younger millennials are mainly involved. Also, events created on social media are very popular with Millennials. For the above reasons, we can state, that social networks provide companies with a space for effective communication of their CSR activities, while it is necessary to take into account the correct targeting of content with respect to the selected segment. A great benefit is the possibility of using analytical tools in evaluating and monitoring the success of socially responsible communication through social networks and obtaining the necessary feedback from the company's stakeholders. It is also necessary to highlight the communication of CSR activities through company websites, which are very popular with Millennials and thus represent one of the most important tools of socially responsible communication. As mentioned in survey results, millennials prefer to search for information on the Internet, so companies should regularly update information on all their CSR activities.

Traditional communication tools, such as, advertising, public relations, sale promotion and direct marketing, are effective in case they are communicated in online environment. The personal sale is relevant for Millennials, if the products are supported by a pricing policy at the level of the upper limit of reference prices. Millennials identify the real social awareness of the company with higher prices of its products, giving them a mark of premium quality. Thus, it is appropriate to use this tool as a premium communication and distribution channel appealing to the importance of the individual in the process of participating in the sustainable development of society.

\section{Conclusion}

In global, Millennials currently have a significant representation and thus form the predominant generation in both the consumer and labour markets. Although the situation in the Slovak Republic is relatively different than in the countries of Western Europe or the USA, Millennials nevertheless have a significant impact on both markets and require companies to behave socially responsibly and to become active creators of long-term social sustainability. For this reason, Millennials represent the target segment for the socially responsible communication.

The most visible benefits of efficient socially responsible communication customized to the target group, i.e. Millennials, includes strengthening the company's image, improving its reputation, building customer relationships and gaining the customers loyalty to the socially responsible brand.

The results from the analysis and survey can have a significant application in practice, especially in predicting purchasing behaviour based on attitudes and behaviour of target segments, but also appropriate targeting of socially responsible communication based on generational stratification. They also provide space for further discussions on CSR in relation to consumers and other stakeholders. 
The issue of Millennials as a target segment of socially responsible communication has, therefore, the potential for deeper research in the future - both qualitatively and quantitatively. To obtain statistical relevance, it would be appropriate to investigate the findings of qualitative research quantitatively. A further qualitative investigation would be appropriate for expanding knowledge and comparing the impact of particular tools of socially responsible communication on Millennials, possibly exploring the socially responsible behaviour of another potential target segment - Post-Millennials - and its comparison with Millennials.

\section{Acknowledgement}

This paper is the outcome of the science project APVV-15-0505: Integrated model of management support for building and managing brand value under the specific conditions of the Slovak Republic.

\section{References}

1. ARNOLD, A., 2018. Millennials and Healthy Living: It's About Online Content, Not Doctors' Visits. In: Forbes [online]. Forbes, 2018. [accessed: 2020-03-15]. Available from: https://www.forbes.com/sites/andrewarnold/2018/02/25/millennialsand-healthy-living-itsabout-online-content-not-doctors-visits/\#11a91d2f32f2

2. BERTHIAUME, D., 2015. Millennials choose retailers for different reasons than elders. In: Chain-StoreAge [online]. Chain-StoreAge, 2012. [accessed: 2020-03-15]. Available from: https://www.chainstoreage.com/news/millennials-chooseretailers-different-reasons-elders/

3. BRUHN, M., A. ZIMMERMANN, 2017. Integrated CSR Communications. In: DIEHL, S., KARMASIN, M., MUELlER, B., TERLUTTER, R. and WEDER, F., Handbook of Integrated CSR Communication. Cham: Springer International Publishing, 3-21. ISBN 978-3-319-44700-1.

4. BUCIC, T., J. HARRIS, D. ARLI, 2012. Ethical Consumers Among the Millennials: A Cross-National Study. Journal of Business Ethics. 110(1), 113-131. ISSN 0167-4544.

5. BUSS, D., 2012. US Consumers Less Willing to Pay More for Green Goods - Study. In: Brandchannel [online]. Brandchannel, 2012. [accessed: 2020-03-15]. Available from: https://www.brandchannel.com/2012/09/27/us-consumers-less-willingto-pay-more-forgreen-goods-study/

6. CONE COMMUNICATIONS, 2020. New Cone Communications Research Confirms Millennials as America's Most Ardent CSR Supporters [online]. Cone Communications, 2015. [accessed: 2020-03-15]. Available from: http://www.conecomm.com/news-blog/new-cone-communicationsresearchconfirms-millennials-as-americas-most-ardent-csr-supporters 
7. ESCARENO, I. M. M. et al., 2018. Influence of Social Marketing and CSR Practices of csr in the Millennials Purchase. Revista Universidad Empresa. 20(35), 251-280. ISSN 0124-4639.

8. EURO RSCG, 2020. New Euro RSCG Study Shows Millennials Rejecting Traditional Politics in Favour of Individual Action [online]. Euro RSCG, 2011. [accessed: 202003-15]. Available from: https://www.realwire.com/releases/New-Euro-RSCGStudy-Shows-Millennials-Rejecting-Traditional-Politics-In-Favour-Of-IndividualAction

9. FRY, R., 2016. Millennials are the largest generation in the U.S. labor force. In: Pew Research Center [online]. Pew Research Center, 2016. [accessed: 2020-03-15]. Available from: http://www.pewresearch.org/facttank/2018/04/11/millennials-largest-generation-us-labor-force/

10. GAJANOVA, L., I. PODHORSKA, 2019. Personnel marketing as a social bottom line of corporate social responsibility from the perspective of the support tool for building brand value. In: 8th International Scientific Symposium on Economy of Eastern Croatia - Vision and Growth. Osijek: Josip Juraj Strossmayer University Osijek, 1168-1182. ISSN 1848-9559.

11. GLASS PACKAGING INSTITUTE, 2020. The Millennials: A Generation Invested in Health and the Environment [online]. Glass Packaging Institute, 2011. [accessed: 2020-03-15]. Available from: http://www.gpi.org/sites/default/files/GPITheMillennials-11\%206\%2014-FINAL.pdf

12. GOLUCHOWSKI, J., K. W. SCIANSKA, A. L. JONCZYK, 2015. Gamification in CSR communication. In: Marketing Identity: Digital Life. Trnava: University of Ss. Cyril and Methodius in Trnava, 473-490. ISBN 978-80-8105-779-3

13. HUME, M., 2010. Compassion without action: Examining the young consumers consumption and attitude to sustainable consumption. Journal of World Business. 45(4), 385-394. ISSN 1090-9516.

14. KLIESTIKOVA, J., M. KOVACOVA, M. RADISIC, 2018. CSR as an innovative concept of SME's brand management in globalised market conditions. In: Proceedings of International scientific conference Globalization and its socio-economic consequences 2018, Zilina: University of Zilina, 608-615. ISBN 978-80-8154-249-7.

15. KRIZANOVA, A., L. GAJANOVA, 2016. The importance of CSR implementation. In: Proceedings of the CBU International Conference on Innovations in Science and Education (CBUIC). Prague: Central Bohemian University, 515-519. ISBN 978-8088042-04-4.

16. LANDRUM, S., 2017. Millennials Driving Brands to Practice Socially Responsible Marketing. In: Forbes [online]. Forbes, 2017. [accessed: 2020-03-15]. Available from: https://www.forbes.com/sites/sarahlandrum/2017/03/17/millennialsdriving-brands-topractice-socially- 
responsiblemarketing/?fbclid=IwAR1luYz2QzqYZ

MXH9AotPBivY18jTv9TTPXEpfGPOvlTRNmpdKjAPHV2xo\#19b83ce4990b

17. LEE, Y. J., E. HALEY, 2019. Role of variability in cultural dimensions across generations in the context of CSR advertising in an East Asian market. International Journal of Advertising. 38(1), 116-138. ISSN 0265-0487.

18. LIZBETINOVA, L. et al., 2019. Application of Cluster Analysis in Marketing Communications in Small and Medium-Sized Enterprises: An Empirical Study in the Slovak Republic. Sustainability. 11(8), art. no. 2302. ISSN 2071-1050.

19. LUO, X., C. B. BHATTACHARYA, 2009. The Debate over Doing Good: Corporate Social Performance, Strategic Marketing Levers, and Firm-Idiosyncratic Risk. Journal of Marketing. 73(6), 198-213. ISSN 0022-2429.

20. MCCRINDLE, M., 2014. The ABC of XYZ: Understanding the Global Generations. Kindle Edition. ISBN 978-0-9924839-0-6.

21. MCWILLIAMS, A., D. SIEGEL, 2001. Corporate Social Responsibility: A Theory of the Firm Perspective. The Academy of Management Review. 26(1), 117-127. ISSN 0363-7425.

22. MEDIAGURU., 2020. Pro CSR budou stěžejní sociální média [online]. Mediaguru, 2015. [accessed: 2020-03-15]. Available from: [Online]. https://www.mediaguru.cz/clanky/2015/06/pro-csr-budou-stezejni-socialnimedia/

23. MORAVCIKOVA, D. et al., 2017. Green marketing as the source of the competitive advantage of the business. Sustainability. 9(12), art. no. 2218. ISSN 2071-1050.

24. MORSING, M., M. SCHULTZ, 2006. Corporate social responsibility communication: Stakeholder information, response and involvement strategies. Business Ethics: A European Review. 15(4), 324-338. ISSN 0962-8770

25. NIELSEN, 2020. Green Generation: Millennials Say Sustainability Is a Shopping Priority. In: Nielsen [online]. Nielson, 2015. [accessed: 2020-03-15]. Available from: http://www.nielsen.com/us/en/insights/news/2015/green-generationmillennials-saysustainability-is-a-shopping-priority

26. RIMARCIK, M., 2007. Štatistika pre prax. Kosice: Marian Rimarcik. ISBN 978-80969813-1-1.

27. SHELTON GROUP, 2020. Millennial Pulse 2017 Special Report [online]. Shelton Group, 2017. [accessed: 2020-03-15]. Available from: https://storage.googleapis.com/sheltongroup/Pulse\%20Reports/ Millennial\%20Pulse\%20FINAL.pdf

28. SCHOLDER, E. P., D. J. WEBB, L. A. MOHR, 2006. Building Corporate Associations: Consumer Attributions for Corporate Socially Responsible Programs. Journal of the Academy of Marketing Science. 34(2), 147-157. ISSN 0092-0703. 
29. SROKA, W., R. SZANTO, 2018. Corporate Social Responsibility and Business Ethics in Controversial Sectors: Analysis of Research Results. Journal of Entrepreneurship, Management and Innovation. 14(3), 111-126. ISSN 2299-7326.

30. VETRAKOVA, M. et al., 2018. Corporate Sustainability in the Process of Employee Recruitment through Social Networks in Conditions of Slovak Small and Medium Enterprises. Sustainability. 10(5), art. no. 1670. ISSN 2071-1050.

31. WAGNER, T., R. J. LUTZ, B. A. WEITZ, 2009. Corporate Hypocrisy: Overcoming the Threat of Inconsistent Corporate Social Responsibility Perceptions. Journal of Marketing. 73(6), 77-91. ISSN 0022-2429.

32. WHEELER, J., 2018. How Millennials Are Changing Philanthropy. In: Forbes [online]. Forbes, 2018. [accessed: 2020-03-15]. Available from: https://www.forbes.com/sites/theyec/2018/08/15/howmillennials-arechanging-philanthropy/\#20ab25237c68

\section{Contact address of the authors:}

doc. Ing. Margaréta Nadányiová, Ph.D., Department of Economics, Faculty of Operation and Economics of Transport and Communications, University of Zilina, Univerzitná 1, 010 26 Žilina, Slovak Republic, e-mail: margareta.nadanyiova@fpedas.uniza.sk

Subhankar Das, Ph.D., Duy Tan University, Fifth Floor, 254 Nguyễn Văn Linh, Thạc Gián, Thanh Khê, Đà Nẵng 550000, Vietnam, e-mail: info.subhankardas@gmail.com 